\title{
PENINGKATAN HASIL BELAJAR PJOK DARING MELALUI GOOGLE MEET PADA SISWA KELAS V SEMESTER 2 SD NEGERI 12 KESIMAN
}

\section{IMPROVING ONLINE PJOK LEARNING OUTCOMES THROUGH GOOGLE MEET FOR CLASS V STUDENTS IN SEMESTER 2 OF SD NEGERI 12 KESIMAN}

\author{
Ida Bagus Gde Oka Gianyar*
}

\author{
Sekolah Dasar Negeri 2 Kesiman, Kesiman, Bali, Indonesia \\ *Email Penulis korespondensi: guuusajii250@gmail.com
}

\begin{abstract}
Abstrak
Penelitian ini bertujuan untuk mengetahui hasil belajar Pembelajaran daring PJOK dengan menggunakan model google Meet pada siswa kelas V SD Negeri 12 Kesiman dan hasil kerjasama antara siswa dengan lingkungan keluaraga pada pembelajaran daring PJOK. Metode yang digunakan yaitu metode penelitian tindakan kelas dan data yang digunakan menggunakan pembelajaran daring dengan menggunakan media Google Meet. Populasi dalam penelitian ini yaitu siswa Kelas V SD Negeri 12 Kesiman Kecamatan Denpasar Timur Kota Denpasar. Pengambilan sampel dalam penelitian ini adalah Siswa Kelas V SD Negeri 12 Kesiman Kecamatan Denpasar Timur Kota Denpasar dengan jumlah 36 siswa. Instrumen yang digunakan dalam penelitian ini adalah hasil belajar pembelajaran daring PJOK dengan menggunakan media google Meet. Hasil dari penelitian ini menunjukan bahwa Hasil Belajar siswa SD Negeri 12 Kesiman Kecamatan Denpasar Timur Kota Denpasar pada pra Siklus ketuntasan klasikal 55,565\%. Ketuntasan klasikal siklus I 80,56\% ada peningkatan 25,00 \% dari pra siklus sedangkan ketuntasan klasikal siklus II 94,44\% ada peningkatan dari pra 38,88\% dan 13,88\% dari Siklus I. Berdasarkan penelitian ini direkomendasikan agar guru PJOK lebih menonjolkan nilai karakter siswa dalam mengkondisikan anggota keluarga agar lebih banyak terlibat dan perencanaan pembelajaran daring ini agar dipersiapkan sesuai dengan materi yang akan diajarkan.
\end{abstract}

Kata-Kata Kunci: Media Google Meet; Hasil Belajar

\begin{abstract}
The study aimed to identify study results online learning PJOK model using google meet in public school students V 12 Kesiman and the cooperation between students with online learning in environmental family. PJOK Methods used in the methodology of class and the data used using online learning by using google meet. Media Of the population is public school students V 12 Kesiman Denpasar District East Of Denpasar city. The sample collection in this research was public school students V 12 kesiman Denpasar district east of Denpasar city 36 by the number of students. An instrument used in this research is learning outcomes of learning online PJOK is using google meet. The media result of this research suggests that study results of public school students 12 Kesiman Denpasar district East of Denpasar on pre cycle exhaustiveness Classical 55,565 \%. Exhaustiveness Classical cycle I 80,56 \% there was increased 25,00 $\%$ from pre cycles while exhaustiveness Classical cycle II 94,44\% it increases from pre 38,88\% and $13,88 \%$ from the cycle I . Based on research is recommended that teachers PJOK is more to highlight the value of character of students in conditioned your family members to give more engaged and planning online learning this so be prepared in accordance with the material will be taught.
\end{abstract}

Keywords: Google Meet; Media Learning Outcomes

\section{PENDAHULUAN}

Terjadinya pandemi Covid-19 memberikan dampak yang besar bagi semua sektor, tidak terkecuali sektor pendidikan. Pendidikan di sekolah tidak dapat dilaksanakan sebagaimana mestinya. Sekolah tidak diperkenankan melaksanakan pembelajaran tatap muka di sekolah guna mencegah penyebaran Covid-19. Keselamatan siswa, guru, dan karyawan merupakan hal yang paling utama. Namun begitu, proses pembelajaran tidak boleh berhenti. 
Untuk tetap memberikan layanan pendidikan bagi siswa, pemerintah menetapkan kebijakan Belajar Dari Rumah (BDR) sejak awal pandemi Covid-19 menyebar di Indonesia, yaitu bulan Maret 2020. Kebijakan pemerintah tentang Belajar Dari rumah tersebut tertuang dalam Surat Edaran Nomor 4 Tahun 2020 yang diterbitkan pada 24 Maret 2020. Kebijakan Belajar Dari Rumah ini masih terus berjalan meski sudah berganti tahun ajaran dikarenakan pandemi belum juga berakhir.

Berdasarkan Surat Edaran Sesjen Nomor 15 Tahun 2020 tentang pedoman penyelenggaraan Belajar Dari Rumah dalam masa darurat penyebaran Corona Virus Disease (Covid-19), pelaksanaan BDR dilakukan dengan pembelajaran jarak jauh (PJJ) yang dibagi ke dalam dua pendekatan, yaitu pembelajaran jarak jauh dalam jaringan (daring) dan pembelajaran jarak jauh luar jaringan (luring). Dalam pelaksanaannya, sekolah dapat memilih pendekatan tersebut sesuai dengan kondisi sekolah. SD Negeri 12 Kesiman menyusun kurikulum tingkat satuan pendidikan tahun ajaran 2020/2021 dengan menyesuaikan kondisi darurat Covid-19. Proses pembelajaran dilaksanakan melalui sistem kombinasi, yaitu pembelajaran daring dan luring. Dikutip dalam laman kemendikbud bahwa dalam pelaksanaan pembelajaran daring, kemendikbud mengimbau guru untuk menghadirkan pembelajaran yang menyenangkan. Namun, kenyataan di lapangan, pembelajaran daring yang dilaksanakan selama ini belum dapat meningkatkan motivasi siswa dalam belajar.

Covid-19 yang terjadi di berbagai negara termasuk Indonesia berdampak pada berbagai bidang termasuk pendidikan. Saat ini dunia pendidikan sedang menghadapi permasalahan yang cukup kompleks. Serangan virus tersebut berdampak pada penyelenggaraan pembelajaran di semuajenjang pendidikan. Tentunya tidak ada banyak kendala pada jenjang perguruan tinggi dan sebagian sekolah menengah yang sudah terbiasa menerapkan pembelajaran online, namun tidak demikian dengan jenjang pendidikan dasar (sekolah dasar) yang bahkan tidak diperbolehkan membawa perangkat komunikasi (handphone) ke sekolah atau ke ruang kelas. Pembelajaran daring membuat siswa memiliki keleluasaan waktu belajar, dapat belajar kapanpun dan dimanapun. Siswa dapat berinteraksi dengan guru menggunakan beberapa aplikasi seperti Meet, video converence, telepon atau live chat, zoom maupun melalui whatsapp group. Pembelajaran ini merupakan inovasi pendidikan untuk menjawab tantangan akan ketersediaan sumber belajar yang variatif. (Nakayama M, Yamamoto H, 2007: 200).

Pandemi covid-19 yang terjadi di Indonesia sangat mempengaruhi kegiatan belajar mengajar di sekolah dasar, sehingga kegiatan belajar mengajar yang awalnya dilakukan dengan bertatap muka langsung di kelas harus beralih dengan pembelajaran secara daring atau jarak jauh. Hal ini tentu saja memberikan dampak pada pembelajaran PJOK di SD Negeri 12 Kesiman diantaranya pembelajaran PJOK yang tidak dapat terlaksana tatap muka, Hal ini berpengaruh dengan pola pikir guru PJOK dengan siswa dimana pembelajaran dialihkan dengan sistem daring. Permasalahan yang tampak adalah model pembelajaran yang menyesuaikan kebutuhan kondisi pada kuota internet siswa.

Pembelajaran daring PJOK ini juga merubah dministrasi guru yang awalnya tatap muka disesuaikan dengan masa pandemi covid-19, disamping protokol kesehatan juga keselamatan dalam mengerjakan tugas berupa gerakan fisik. Permasalahan selanjuttnya adalah piranti handphone siswa kebanyakan belum punya dan mengandalkan milik orangtua. Kerjasama guru PJOK dengan orangtua terhambat karena permasalahan pekerjaan sehingga tugas yang diberikan kepada siswa banyak yang tidak dikerjakan.

Model pembelajaran dengan Google Meet mengadopsi model pembelajaran Brain Based Learning merupakan salah satu pembelajaran yang berbasis neurosains. Neurosains adalah ilmu yang mempelajari sistem syaraf otak dengan seluruh fungsinya, seperti bagaimana proses berpikir terjadi dalam otak manusia (Muhtadi, 2019:47). Masih dalam 
Muhtadi (2019:55), penelitian neurosains kognitif menunjukkan bahwa berbagai faktor lingkungan dapat menarik dan mempertahankan perhatian orang.

Menurut Sunaryo (2017: 89), model Brain Based Learning merupakan suatu model yang memberdayakan potensi otak siswa yang juga dalam pembelajarannya harus membuat suasana kelas menjadi menyenangkan dan nyaman, sehingga siswa dapat mengoneksikan pelajaran yang diterima dengan baik. Merujuk pada konsep kontruktivisme pendidikan, keberhasilan belajar siswa ditentukan oleh seberapa mampu mereka membangun pengetahuan dan pemahaman tentang suatu materi pelajaran berdasarkan pengalaman belajar yang mereka alami sendiri (Nur, 2016: 29).

Tahapan model pembelajaran Brain Based Learning yang disampaikan oleh Jensen (dalam Solihat, 2017: 453-454) antara lain (1) pra-pembelajaran; (2) persiapan; (3) inisiasi dan akuisisi; (4) elaborasi; (5) inkubasi dan memasukkan memori; (6) verifikasi dan pengecekan keyakinan; dan (7) perayaan dan integrasi. Dikarenakan pembelajaran dilaksanakan secara daring, model Brain Based Learning lebih disederhanakan sehingga mudah untuk diterapkan. Peneliti yang juga sebagai guru PJOK SD Negeri 12 Kesiman mempunyai inisiatif untuk membuat model pembelajaran daring berupa Google Meet.

\section{METODE PENELITIAN}

Penelitian yang dilakukan oleh guru yang berfokus pada masalah yang ada di kelas maya yang bertujuan memperbaiki mutu praktik pelajaran di kelas maya. Penelitian Tindakan adalah jenis pendekatan riset criticalisme merupakan salah satu model penelitian yang menerapkan paradigma hasil penelitian tidak hanya berupa pengetahuan tetapi juga perubahan atau peningkatan mutu semua komponen yang diteliti, Sedangkan Penelitian Tindakan Kelas (Meet Action Research) adalah Penelitian tindakan yang dilakukan guru di kelas maupun kelas maya. PTK dilaksanakan demi perbaikan dan peningkatan praktik pembelajaran secara berkesinambungan. Tujuan PTK ialah pengembangan kemampuanketerampilan guru untuk menghadapi permasalahan aktual pembelajaran di kelas maya dan atau di sekolahnya sendiri. Tujuan penyerta penelitian tindakan kelas ialah dapat ditumbuhkannya budaya meneliti dikalangan pendidik

\section{Subjek dan Objek Penelitian}

Subjek penelitian yang terlibat dalam ujicoba penelitian tindakan adalah Pembelajaran daring PJOK menggunakan model Google Meet pada siswa 36 orang.

\section{Instrumen Tes}

Alat ukur yang digunakan dalam penelitian ini adalah hasil belajar pembelajaran daring PJOK menggunakan model google Meet yang digunakan dalam penelitian ini adalah pengembangan sendiri dengan mengacu pada metode atau prosedur yang sudah ditentukan. Prosedur yang dilakukan disesuaikan dengan tingkat kebutuhan yang diperlukan

\section{Prosedur Penelitian}

Prosedur penelitian yang digunakan dalam penelitian ini adalah penelitian tindakan kelas (PTK). Penelitian tindakan kelas merupakan penelitian yang dilaksanakan oleh guru dalam meningkatkan kualitas pembelajaran di kelas daring maupun Kelas Luring. Penelitian tindakan kelas berangkat dari masalah sehingga penelitian ini diharapkan dapat memecahkan masalah tersebut. Setiap siklus dalam desain pelaksanaannya meliputi perencanaan tindakan pelaksanaan tindakan,observasi, dan refleksi. 


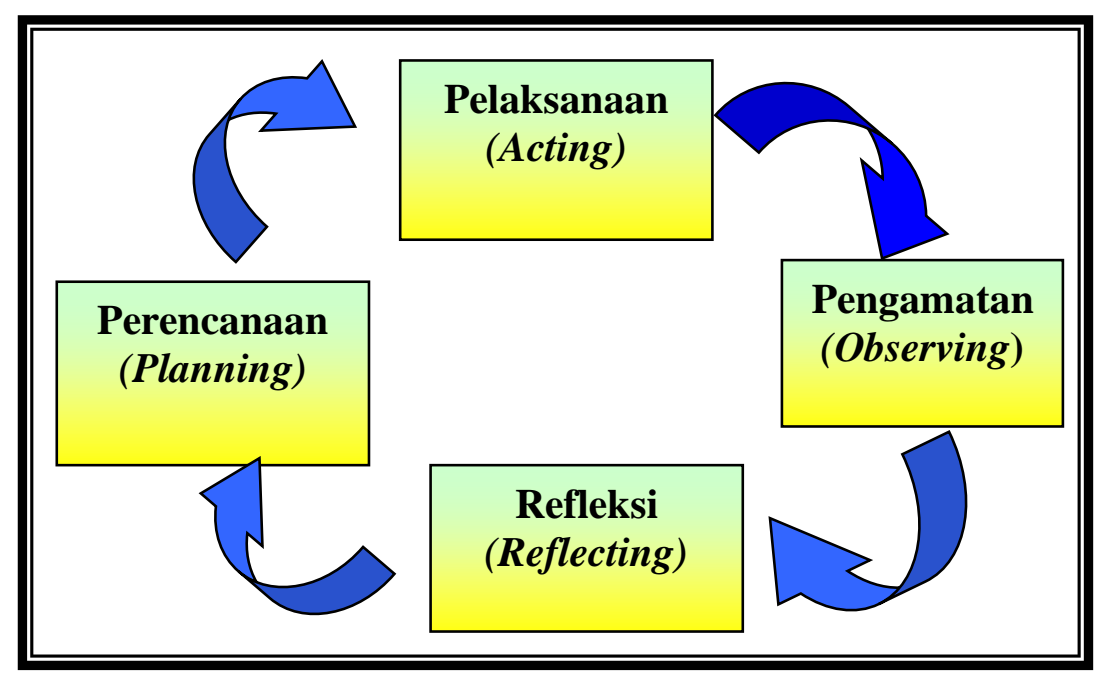

Gambar 1. Desain Penelitian Menurut Kurt Lewin

Dengan berpedoman pada refleksi awal tersebut, maka prosedur pelaksanaan penelitian tindakan kelas ini meliputi: (1) perencanaan, (2) pelaksanaan tindakan, (3) observasi, dan (4) refleksi dalam setiap siklus

\section{Analisis Data}

Penelitian tindakan kelas ini yang dikumpulkan adalah data hasil belajar PJOK yang merupakan produk atau hasil dari pelaksanaan Tindakan. Pengumpulan data dilaksanakan dengan menggunakan butir butir soal dalam tes tertulis. Analisis data dilakukan secara deskriptif kuantitatif seperti menentukan rata-rata (mean), median ,dan modus yang selanjutnya dipergunakan untuk melakukan kajian dalam tindakan refleksi setiap siklus menggunakan rumus Mean yakni: (Akbar dalam Widayanti, 2018: 61)

$$
\mathrm{M} \quad=\frac{\sum \mathrm{FX}}{N}
$$

Keterangan:

$$
\begin{array}{ll}
\mathrm{M} & =\text { Mean } \\
\mathrm{Fx} & =\text { Jumlah sekor seluruh siswa } \\
\mathrm{N} & =\text { Jumlah siswa }
\end{array}
$$

Kreteria hasil belajar PJOK berdasarkan PAP dapat dilihat pada Tabel 1.

Tabel 1. PAP Hasil belajar PJOK

\begin{tabular}{cc}
\hline Persentase & Hasil belajar PJOK \\
\hline $90 \%-100 \%$ & Sangat Baik \\
$80 \%-89 \%$ & Baik \\
$65 \%-79 \%$ & Sedang \\
$55 \%-64 \%$ & Cukup \\
$0 \%-54 \%$ & Kurang \\
\hline
\end{tabular}

Sumber: Akbar dalam Widayanti, 2018

a. Ketuntasan belajar siswa sebesar $85 \%$

Ketuntasan belajar yang dimaksud dalam penelitian ini adalah jumlah siswa yang memperoleh hasil belajar PJOK dengan katagori sedang, keatas.

Untuk menentukan ketuntasan belajar digunakan rumus : 


$$
\begin{aligned}
& \mathrm{KB}=\frac{N>65}{N} \times 100 \% \\
& \text { Keterangan : } \\
& \mathrm{KB}=\text { Ketuntasan Belajar } \\
& \mathrm{N} \quad=\text { Jumlah siswa }
\end{aligned}
$$

b. Daya Serap

$$
\begin{aligned}
& \text { DS }=\frac{M}{S T I} \times 100 \% \\
& \text { DS }=\text { Daya Serap } \\
& \text { STI }=\text { Skor tertinggi ideal } \\
& \mathrm{M}=\text { Mean }
\end{aligned}
$$

c. Keberhasilan Hasil belajar PJOK Siswa secara klasikal adalah dengan kategori baik, yakni rata rata persentase hasil belajar PJOK mencapai $80 \%$ keatas.

\section{HASIL DAN PEMBAHASAN}

\section{Hasil Penelitian}

\section{Siklus I}

Kegiatan yang dilakukan dalam tahap refleksi adalah menganalisanya jalannya pembelajaran dan menganalisis perangkat evaluasi pembelajaran daring PJOK menggunakan model Google Meet dalam Permainan Sepak Bola. Berdasarkan perangkat evaluasi ditemukan beberapa kelemahan antara lain:

a) Media pembelajaran melalui PPT bentuk Video masih kurang mengena pada siswa tugas banyak yang kurang memahami.

b) Pada saat guru menjelaskan materi pembelajaran banyak siswa yang kurang memperhatikan instruksi guru/peneliti siswa kurang paham dengan materi atau tujuan dari pembelajaran tersebut hal ini ditunjukan dengan hasil dibawah ini.

Berdasarkan hasil pengamatan dan respon pada siklus I diketahui bahwa hasil yang diperoleh belum memenuhi keinginan peneliti dalam pembelajaran daring PJOK menggunakan model Google Meet dalam Permainan Sepak Bola maka pada refleksi peneliti dan teman sejawat menganalisa kekurangan dan kelemahan guru terutama:

a) Bahan ajar guru harus lebih kreatif lagi terutama dalam kata perintah.

b) Media pembelajaran yang dibuat terutama video durasi waktu untuk diperpendek tapi tidak mengurangi isi materi.

c) Peneliti harus mengetahui kesulitan siswa dalam membuka dan mengirim tugas melalui google Meet dengan share Screen.

d) Diskusi dan kerjasama antar peneliti dan guru yunior diperkuat lagi, agar permasalahan segera teratasi.

Melihat hasil kinerja pada siklus I yang kurang memenuhi maka diperlukan perbaikan pada tindakan siklus II. Kelemahan dan kekurangan yang terjadi selama siklus I ketuntasan klasikal baru mencapai 80,56\% masih kurang dari yang ditetapkan yaitu 85\% maka akan dicarikan solusi dan akan dilakukan perbaikan-perbaikan dalam melakukan siklus II agar mencapai ketuntasan klasikal diatas $85 \%$.

\section{Siklus II}

Berdasarkan hasil penelitian Siklus II sebagaimana dipaparkan di atas, dapat dinyatakan hal-hal berikut: 
a) RPP dan media dibuat secara paradigmatik yang sesuai dengan kaidah pengunaan materi pembelajaran daring PJOK menggunakan model Google Meet dengan materi Teknik menggiring, menendang, menerima, mengoper, dan menyundul bola.

b) Pelaksanaan sesuai dengan sistematika yang didasarkan kepada penerapan metode atau model pembelajaran tertentu.

c) Hasil belajar siswa pembelajaran daring PJOK menggunakan model Google Meet dengan materi Teknik menggiring, menendang, menerima, mengoper, dan menyundul bola mengalami peningkatan.

\section{Pembahasan Penelitian}

Pengamatan pada siklus I dilakukan oleh peneliti dan teman guru sebagai teman sejawat pada kegiatan di dalam proses penelitian melalui lembar observasi. Pada observasi yang pengamat lakukan dalam proses kegiatan pembelajaran daring PJOK menggunakan model Google Meet dengan materi Teknik menggiring, menendang, menerima, mengoper, dan menyundul bola diperoleh temuan-temuan sebagai berikut:

a) Peneliti memberikan apersepsi hasilnya baik;

b) Penguasaan Peneliti terhadap materi hasilnya cukup;

c) Pengelolaan siswa hasilnya kurang karena banyak siswa yang belum paham dengan model Google Meet yang baru pertama kali digunakan oleh siswa.

d) Penggunaan media pembelajaran peneliti yang kurang tepat pada siswa

e) Pemberian contoh melalui demonstrasi hasilnya kurang karena guru/peneliti masih menggunakan cara lewat kata kata atau verbalisme.

f) Bimbingan peneliti dibantu oleh siswa yang sudah bisa kepada siswa yang lainnya secara individu atau kelompok hasilnya kurang. Dilihat dari nilai hasil kegiatan pada siklus II perbaikan pembelajaran siklus II semua siswa kelas V SD Negeri 12 Kesiman dapat melakukan kegiatan penelitian ini dengan hasil yang baik, dari 36 siswa yang melakukan penilaian pada penelitian ini sudah menunjukan kemampuan yang baik. Pada siklus II ini, peneliti berupaya agar terjadi peningkatan hasil pembelajaran daring PJOK menggunakan model Google Meet dengan materi Teknik menggiring, menendang, menerima, mengoper, dan menyundul bola dengan baik dan benar dengan mengacu pada kegiatan siklus I. Sehingga penerapan kegiatan pembelajaran daring PJOK menggunakan model Google Meet dengan materi Teknik menggiring, menendang, menerima, mengoper, dan menyundul bola dalam penelitian dapat dioptimalkan kembali pada kegiatan pembelajaran selanjutnya. Perbaikan perangkat pembelajaran dan pencapaian indikator yang jelas siswa dapat melakukan instruksi guru/peneliti secara baik dan benar melalui Video Pembelajaran.

Tabel 2. Hasil Evaluasi Pra Siklus, Siklus I, dan Siklus II

\begin{tabular}{llccc}
\hline \multirow{2}{*}{ No Uraian } & \multirow{3}{c}{ Hasil Evaluasi } \\
\cline { 3 - 5 } & & Pra Siklus & Siklus I & Siklus II \\
\hline 1 & Jumlah Nilai & 2350 & 2600 & 2840 \\
2 & Rerata & 65,28 & 72,12 & 78,89 \\
3 & Remidi & 16 & 7 & 2 \\
4 & Pengayaan & 20 & 29 & 34 \\
5 & Prosentase Ketuntasan & 55,56 & 80,56 & 94,44 \\
\hline
\end{tabular}

Sumber: SD Negeri 12 Kesiman 


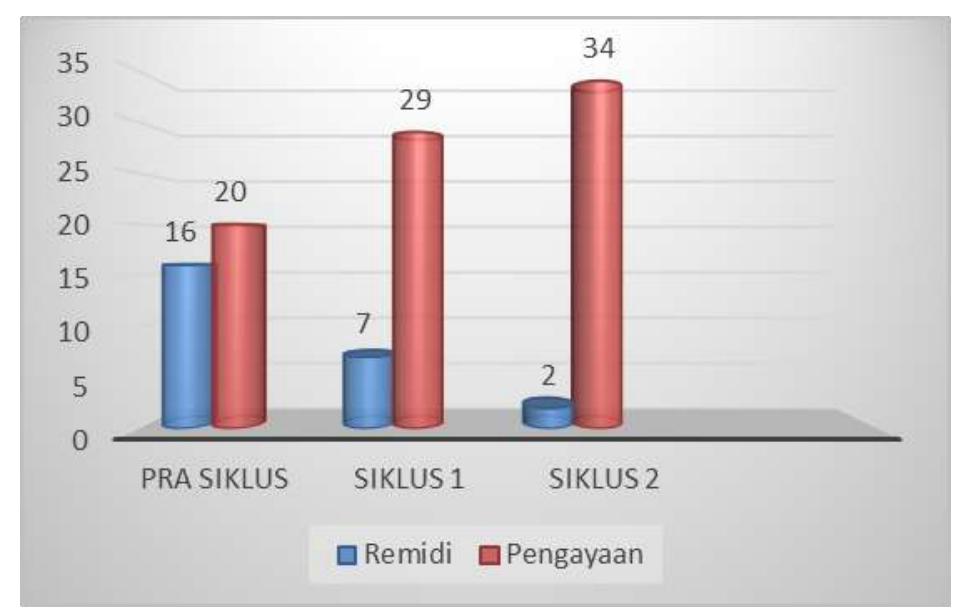

Gambar 2. Grafik Ketuntasan Hasil Evaluasi

\section{KESIMPULAN DAN SARAN}

\section{Kesimpulan}

Dari berbagai uraian yang telah penulis paparkan di atas, maka dapat diambil beberapa simpulan yaitu:

- Kegiatan Pembelajaran dengan model Google Meet sangat perlu digunakan karena dapat meningkatkan keaktifan siswa dalam merumuskan masalah (menanya) dan berkomunikasi dengan guru ataupun temannya. Jika siswa sudah dapat merumuskan masalahnya sendiri, siswa akan memahami materi yang diajarkan sehingga dapat meningkatkan prestasi belajar siswa.

- Kegiatan Pembelajaran dengan model Google Meet sangat perlu digunakan karena jika siswa sudah mendapatkan informasi sesuai dengan yang mereka harapkan, maka prestasi belajar mereka akan meningkat.

- Kegiatan Pembelajaran dengan model Google Meet sangat penting dilakukan karena dalam kegiatan ini mampu memberikan dampak iringan yaitu terlatihnya cara berkomunikasi dalam hal memberi dan menerima informasi dengan baik dan benar.

- Dengan bantuan Google Meet dalam pembelajaran, siswa dapat aktif memecahkan masalah yang diberikan secara berkelompok maupun individu saat pembelajaran sehingga dapat meningkatkan prestasi belajar siswa.

\section{Saran}

- Kepada bapak dan ibu guru, Pembelajaran dalam Google Meet agar memvariasikan kegiatan Pembelajaran dengan metode atau media pembelajaran daring dengan Fitur Google Workspace yang lain seperti Zoom, Cloud, Google Classroom dll. Hal ini akan menambah pengalaman siswa dan menghilangkan kejenuhan siswa dalam menerima materi pelajaran.

- Bagi guru hendaknya tidak berhenti belajar dan berkreasi dalam memodifikasi berbagai macam model, metode, ataupun kegiatan pembelajaran lainnya dengan didukung oleh media yang inovatif.

\section{DAFTAR PUSTAKA}

AnNur. Sagala, S. (2010). Kemampuan Professional Guru dan Tenaga Kependidikan. Bandung: Alfabet.

M, Yamamoto H, \& S. R. (2007). The Impact of Learner Characterics on Learning 
Performance in Hybrid Courses among Japanese Students. Elektronic Journal ELearning, Vol.5(3).1.

Menteri Pendidikan. (2020). Surat Edaran Nomor 3 Tahun 2020 Tentang Pelaksanaan Pendidikan dalam Masa Darurat CoronaVirus (COVID-19).

Muhtadi, Dr. Ali. (2019). Modul Pembelajaran Inovatif. Jakarta.

Nur, Iyan Rosita Dewi. (2016). Meningkatkan Kemampuan Berpikir Kreatif Matematis dan Kemandirian Belajar Siswa dengan Menggunakan Model Pembelajaran Brain Based Learning. Jurnal Pendidikan UNSIKA, Volume 4, Nomor 1.

Solihat, Amalia, Regina Lichteria P., dan Dadan Djuanda. (2017). Penerapan Model Pembelajaran Brain Based Learning. Jurnal Pena Ilmiah, Volume 2, Nomor 1, halaman 453-454

Sunaryo, Yoni dan Ida Nuraida. (2017). Pengaruh Penerapan Model Pembelajaran Brain Based Learning terhadap Kemampuan Pemecahan Masalah Matematik Siswa. Jurnal Penelitian Pendidikan dan Pengajaran Matematika, Volume 3, Nomor 2, halaman 89.

WHO. (2020). Pertanyaan dan Jawaban TerkaitCoronavirus. Diakses 14 Juli 2021, dari https://www.who.int/indonesia/news/novelcoronavirus/qafor_public.

Widayanti, Agnisa. (2018). Penerapan Model Pembelajaran Teknik Make A Match untuk Meningkatkan Motivasi dan Aktivitas Belajar Siswa. Jurnal Pendidikan Akuntansi Indonesia, Volume XVI, Nomor 1 